\title{
DOI: 10.1515/orga-2017-0010 \\ Psychosocial Factors in the Development of Low Back Pain Among Professional Drivers
}

\author{
Friderika Kresal $^{1}$, Tine Bertoncel ${ }^{2}$, Maja Meško ${ }^{3}$ \\ ${ }^{1}$ Fizioterapevtika, Institution of Higher Education, Bogatajeva ulica 15, Medvode, Slovenia \\ tajnistvo@fizioterapevtika.si \\ ${ }^{2}$ MC Erasmus, Erasmus University Rotterdam, Nieuwemarkt 1a 3011, Rotterdam, Netherlands \\ tine.bertoncel@gmail.com \\ ${ }^{3}$ Faculty of Management, University of Primorska, Cankarjeva 5, Koper, Slovenia \\ maja.mesko@fm-kp.si (Corresponding author)
}

\begin{abstract}
Background and purpose: Professional drivers as a group are exposed to high risk of developing low back pain due to ergonomic factors and work conditions. The purpose of the study was to examine to what extent the low back pain occurs among Slovene professional drivers as a result of the development of various psychosocial factors.

Methodology: The study involved 275 respondents (professional bus drivers, car/van drivers, international truck/ lorry drivers, and ambulance car drivers). Hypotheses were tested using multivariate statistical method (regression analysis) and analysis of variance. Data were collected by structured questionnaire comprised of three parts: socio-demographic data, basic psychosocial factors causing low back pain, and incidence, duration and severity of low back pain as a result of psychosocial risk factors, was implemented.

Results: The results of quantitative survey suggest that low back pain is mostly caused by lifting and carrying heavy loads, inadequate working conditions, poor physical fitness, regular nights out, shift work, and stress. Only the impact of gender on low back pain distress among professional drivers was confirmed, predominantly among bus drivers and lorry drivers on international routes. Low back pain occurrence was less common, albeit not statistically significant, among professional drivers of vans and passenger cars.

Conclusion: Our study suggests that psychosocial factors are also important cause for the development of low back pain among professional drivers and can limit the quality of their social and professional lives.
\end{abstract}

Keywords: low back pain; psychosocial factors; professional drivers; prevention; Slovenia

\section{Introduction}

Evidence suggests that around three-quarters of the world's population is confronted with low back pain once in life, most frequently individuals between 20 and 50 years of age, while they are in the prime of their physical and mental abilities and in their most active period of life (Hartvigsen et al., 2000; Tse et al., 2006; Bach \& Cosic, 2008; Knauer et al., 2010; Cox, 2011; Kresal et al., 2015).
Attacks of low back pain due to work-related factors are a common reason for short-term or long-term absences from work, resulting in huge economic burden for both, individuals and society (Thorbjörnsson et al., 2000; Harris \& Rampersaud, 2015; Shojaei et al., 2017). Accordingly, absenteeism due to low back pain represents a major health problem because of long-term medical treatment and early invalidity retirement, as well as socioeconomic factors (Margan et al., 2009). Recent evidence suggests high level 
of absenteeism due to low back pain among professional drivers in Slovenia (Krčevski Škvarc, 2001; Šinigoj et al., 2011; Meško et al., 2012a; Meško et al., 2012b; Kresal et al., 2015).

Evidence also suggests that individuals experience most often the acute phase of low back pain lasting less than 6 weeks, while the sub-acute phase of low back pain lasts between 6 to 12 weeks, and chronic phase of low back pain commonly lasts for more than 3 months (MacNeela et al., 2010; Hanscom et al., 2015) with the remedial procedures and treatment effectiveness being minimal in the latter phase.

Low back pain distress worsens the quality of life and can forces affected individuals into dependency and inability to care for themselves (Aronoff et al., 2000; Tziner \& Birati, 2015; McGill, 2016; Leclerc, 2017). In worst cases, the low back pain leads to a loss of physical functions and muscle tone, causes overall weakness, and reduces well-being through exerting periodic or continuous pain. Consequently, the loss of normal functioning of an individual can indirectly leads to his/her social isolation, which could result in less social activities in his/her spare time, and impaired relations or connections in his/her close environment, stress in the family and possible loss of income. Social disability often causes mental disorders with the emergence of insomnia, irritability, anxiety, depression, and somatic disorders (Van der Beek, 2012; Yoo, 2016; Shojaei et al., 2017).

Waddell (1998) describes low back pain as a medical and health disaster of the last century, to large extend due to existing health care system medical model of western countries. Current system is mainly focused on the identification of symptoms and signs, diagnosing, patient management with physical therapy and anticipation of a positive outcome of treatment, but at the same time ignoring the biological, psychological and social determinants (Gregg et al., 2015). Thus neglecting the need for more holistic treatment of patients with low back pain, which is offered by the biopsychosocial model of treatment (Dedessus-Le-Moustier \& Lerouge, 2011). Professional truck and bus drivers are, due to the specific working positions, a group which is largely exposed to health and other risks while conducting their profession (Miyamoto et al., 2008; Bouffartigue et al., 2010; Jones et al., 2013; Lerouge, 2014; International Spine Study Group, 2015).

Bilban (2014) argues that trucks and cars are not designed to fully meet physiological needs of professional drivers who are often overloaded and exposed to vibrations, uncomfortable seats and limited workspace and prolonged sitting due to forced position while driving and the level of vibrations caused by poor roadway (Funakoshi et al., 2003; Rehn et al., 2005; Szeto \& Lam, 2007; Louit-Martinod et al., 2016). This can result in spine problems and malfunctions of organs in the chest area and abdominal cavities. Due to insufficient blood supply to the lower part of the body caused by prolonged sitting, professional drivers are also exposed to cardio vascular system diseases and high blood pressure. Additionally, they are often exposed to diseases of the locomotor system, especially the lower spine, as well as to psychological problems (Hasle, 2007; Bilban, 2014; Louit-Martinod et al., 2016).

Several studies show strong correlation between low back pain and professional drivers (Videman et al., 2000; Gimeno et al., 2004; Tse et al., 2006; Campbell \& Guy, 2007; Alperovitch Najenson et al., 2010; Dedessus-Le-Moustier \& Lerouge, 2011; Louit-Martinod et al., 2016). Others scholars (Breuer and Brettel, 2012; Knox et al., 2013; Hopayian \& Notley, 2014; Janwantanakul \& Akkarakittichoke, 2017) find high probability for developing the low back pain in certain professions, like lorry drivers, manual workers, and nurses.

The most common cause for low back pain among professional drivers is forced posture and sedentary work, mostly due strong vibrations and increased tone of certain muscles. Heavy physical workload, like heavy lifting, can also results in low back pain among professional drivers (Tamrin et al., 2007; Robb \& Mansfield, 2007). According to Alperovitch Najenson et al. (2010), 45.4 percent of professional drivers experienced low back pain due to the ergonomic factors associated mainly with uncomfortable seats and uncomfortable back supports and the psychosocial factors associated with limited resting time periods during the work day and heavy traffic on bus routes. Several other studies suggest preventive measures in order to reduce work-related stress, drivers' seat improvements to lower whole-body vibrations and forced torso posture, and strong encouragement for more regular sport activities among professional drivers to improve their mental and physical well-being, and work productivity ( $\mathrm{Xu}$ et al., 1997; Okunribido et al., 2007; Chen et al., 2005; Tamrin et al., 2007; Bovenzi, 2010; Gangopadhyay \& Dev, 2012).

Less commonly stated causes for low back pain among professional drivers are psychosocial risk factors such as satisfaction with job, work requirements, lifestyle (little sports activity, poor diet, smoking) and non-prescription medication (pain-killers) (Adams et al., 1999; Proctor et al., 1999; Kerr et al., 2001; Linton, 2001; Okunribido et al., 2007; Robb \& Mansfield, 2007; Rabenu \& Tziner, 2016; Šinigoj et al., 2011; Roblek \& Bertoncelj, 2014; Askenazy, 2014).

The extensive review of scientific and professional literature in the field of occupational risk factors among professional drivers suggests insufficient research based on holistic views of psychosocial risk factors for low back pain in professional drivers.

The main aim of this study was to examine the theoretical foundations of psychosocial risk factors in low back pain, to determine which are the most common psychosocial risk factors for absenteeism, and the extent to which low back pain occurs among Slovenian professional 
drivers as a result of the impact of various psychosocial risk factors. The research question was: What are the most common psychosocial risk factors for absenteeism, the extent to which low back pain occurs among Slovenian professional drivers as a result of the impact of various psychosocial risk factors?

Therefore, in our study, we focused on psychosocial factors for low back pain among professional drivers in order to determine whether and to what extent psychosocial factors affect, in the opinion of the respondents - professional drivers, low back pain occurrence.

\section{Research methodology}

\subsection{Hypotheses}

The following three hypotheses were set for the purpose of the study:

\section{H1: Psychosocial factors influence the occurrence of low back pain among professional drivers}

In recent decades, many scholars have studied different psychosocial risk factors in professional drivers that have direct impact on the low back pain (Grossi, Soares Ängeslevä \& Perski, 1999; Devereux, Buckle \& Vlachonikolis, 1999; Linton, 2001). In this study, psychological factors from different studies were combined and studied whether they can cause and effect the occurrence of low back pain.

H2: Occurrence of low back pain depends on gender, age and years of work among professional drivers

Low back pain typically occurs in the most active period of life when individuals are at the peak of their mental and physical abilities, that is, between 35 and 55 years of age (McBeath, 1970; Magora, 1973; Frymoyer \& Cats Baril, 1991; Margan, Turk, \& Palfy, 2009). Low back pain occurs in both men and women, although some researchers determined that low back pain is more frequent in women (Walsch, Crudas, \& Coggon, 1922; Papageorgiou, 1995). Alcouffe et al. (1999) have determined that the risk factor of low back pain, which is characterized in particular for men, is the years of work. The study investigated whether the age, the gender and the years of work as a professional driver have an effect on the incidence of low back pain and to what extent.

\section{H3: Occurrence of low back pain varies among differ- ent groups of professional drivers}

Truck drivers are particularly exposed to the low back pain. In addition to vibration, approaching the resonance frequency of the spine, they are exposed to the other risk factors, such as a small work space, not ergonomic seats etc. (Bilban, 2014). Taxi drivers are exposed to vehicle vi- bration, unpredictable situations on the road and the stress caused by the drive (Miyamoto et al., 2008). The study investigated whether there is any variability in low back pain occurrence among professional drivers of various vehicles (buses, taxis, and commercial vehicles).

\subsection{Sample description}

In 2013 there were 8320 professional drivers in Slovenia. Out of this population, a stratified sample of 300 to 350 professional drivers was selected. Descriptive statistics was as follows: 93.8 percent of respondents were men and 6.2 percent were women, aged from 23 to 66 years with mean age of 41.6 years. Respondents weighed between 55 and $156 \mathrm{~kg}$, on average $83 \mathrm{~kg}$. The smallest respondent was $162 \mathrm{~cm}$ and the highest was $191 \mathrm{~cm}$ tall, average height was $175.6 \mathrm{~cm}$.

\subsection{Survey questionnaire}

The survey questionnaire was prepared and previously tested on a pilot sample of 35 professional drivers in order to evaluate the reliability and validity of the instrument. The survey questionnaire consisted of 46 questions: 8 questions were open type, 12 closed type with one possible answer, 1 closed type with multiple-choice answers, 2 questions were semi-open type (the option "other", in which the respondent added the appropriate answer), 23 questions were closed type on different scales from 1 to 7 (never - very often, medium - very strong, can stand without problems - very difficult to stand, does not affect low back pain - a significant impact on low back pain, not true - absolutely true).

The questionnaire was comprised of three sets of questions:

- First, to determine socio-demographic data: gender, age, weight and height, marital status of respondents, type of vehicle, years as a professional driver, number of days of absence from work, number of days absent from work due to low back pain, satisfaction with work, personal life, and leisure time, the frequency of engaging in sports and the reasons for doing sport, and lifestyle (smoking, drinking, use of painkillers.

- Second, the following basic psychosocial factors were explored: dissatisfaction with work, bad relationships between colleagues, poor attitude of managers, working in shifts, lifting and carrying heavy loads, inadequate working conditions, job loss, stress and personal dissatisfaction, misunderstanding of a partner, divorce, death of close family member, drinking coffee more than three times a day, smoking, regular nights out, poor physical condition and personal hygiene.

- Third, the incidence and severity of low back pain as 
a result of psychosocial risk factors were explored by asking respondents how often they feel low back pain, how intense was and how difficult it was to deal with. Respondents were also asked whether the low back pain persists after resting, regular exercise and medication, which posture pain was the strongest, how often they conduct exercises to prevent low back pain, how much time per day they devote to rest, and which activities were considered as active rest.

\subsection{Study progress}

Data collection was conducted in 2012 and 2013. Online survey was anonymous and active from October till December 2013 and was limited to respondents in geographical area of the Republic of Slovenia, covering altogether 275 respondents. It was estimated to be a representative sample. Completing the survey took respondents from 20 to 30 minutes on average. Most of the surveys were completed by interviewing the respondents, because of the complexity of questions and the need for additional explanations. In almost half of all cases, respondents were initially afraid to answer questions, mainly due to fear of losing their jobs, therefore complete anonymity was provided.

\section{Results of the study}

\subsection{Descriptive statistics for the sample of the study}

Among the respondents $93.8 \%$ are men and $6.2 \%$ women, aged between 23 and 66 years. Average age is 41.6 years, with a standard deviation of 8.9 years. Respondents weight between 55 and $156 \mathrm{~kg}$, on average, $83 \mathrm{~kg}$, with a standard deviation of $12.2 \mathrm{~kg}$. Most of the respondents (38.5\%) live in a consensual union, followed by those who are married (28.7\%) and single (19.3\%). A quarter of respondents are city bus drivers, $24.4 \%$ professional car drivers, $16.0 \%$ of them drive truck, and $8.4 \%$ of the respondents chose the answer »other « (van, ambulance or taxi drivers). They work as professional drivers on average 13.5 years, with a standard deviation of 8.3 years. In the last year they were absent from work on average 16.6 days, with a standard deviation of 13.4 days. Due to the low back pain they were absent on average 5.5 days, with a standard deviation of 11.3 days.

More than half of all respondents (53.5 percent) were satisfied with their work, and 40.4 percent of them were partially satisfied with their work. 72.7 percent of all respondents were satisfied with their personal life, and 25.5 percent of them were partially satisfied. 77.8 percent spent their free time with friends, 75.3 percent with their family, and/or 53.1 percent watching TV. 33.8 percent of all respondents were involved in sport activities 2 to 3 times a month, 26.5 percent once a week, meaning more than half of them did sports in order to maintain good physical condition.

36.7 percent of all respondents were regular smokers that were smoking on average for 17.8 years, 4.4 percent were occasional smokers that were smoking on average for 14.7 years. 22.9 percent of all respondents had smoked in the past but ceased to smoke. Alcohol was occasionally consumed by 78.9 percent of all respondents, and 1.8 percent of respondents were regular drinkers. 74.9 percent of all respondents were occasionally taking painkillers, and 9.8 percent were using them regularly.

In the Table 1 the psychosocial factors were presented assessed by respondents on a scale from 1 (no impact on low back pain) to 7 (high impact on low back pain).

Almost half of all respondents (48.4 percent) claimed that low back pain was the strongest when bending forward, 40.4 percent stated that they exercise at least once a week in order to prevent lower back pain, but 40.0 percent of them never exercised. 36.0 percent of all respondents devoted time to rest from one to two hours, 30.5 percent of them rested from half an hour to one hour, and 27.3 percent rested for more than two hours a day. 37.5 percent of all respondents did, as active rest, walking/trekking, 22.5 percent were reading books, and 21.5 percent of them were listening to music.

\subsection{Testing of hypotheses}

The first hypothesis "Psychosocial factors cause and effect the occurrence of low back pain among professional drivers" was verified through multiple regression analysis. Stepwise regression analysis was performed (Boslaugh \& Watters, 2008).

In the regression model, a dependent variable the incidence of low back pain and as independent variables the psychosocial factors were included.

Model 1: Psychosocial factors cause and effect the occurrence of low back pain among professional drivers.

Five regression models were developed through the "stepwise" method. The first regression model included variable inadequate working conditions, which explained 34.4 percent of the variability of variable incidence of low back pain. The second regression model included variable dissatisfaction with work, which explained 4.7 percent of the variability, and the third regression model included variable shift work, which explained 1.8 percent of the variability. The fourth regression model included variable job loss, which explained 1.1 percent of the variability, and the fifth regression model included variable disrespectful attitude of managers, which further explains 0.9 percent of the variability of the dependent variable. 
Table 1: Descriptive statistics of psychosocial factors

\begin{tabular}{|c|c|c|}
\hline Psychosocial factors & $\mathbf{M}$ & SD \\
\hline dissatisfaction with work & 2.7 & 1.9 \\
\hline bad relations among colleagues & 2.1 & 1.2 \\
\hline disrespectful attitude of managers towards employees & 2.6 & 1.8 \\
\hline shift work & 4.0 & 1.1 \\
\hline lifting and carrying heavy loads & 5.1 & 1.3 \\
\hline $\begin{array}{l}\text { unsuitable working conditions (working space, cabin seat, noise, } \\
\text { traffic, vibrations) }\end{array}$ & 5.0 & 0.9 \\
\hline job loss & 3.1 & 1.5 \\
\hline stress & 3.3 & 1.7 \\
\hline personal dissatisfaction & 3.0 & 1.9 \\
\hline misunderstanding of partners & 2.4 & 1.8 \\
\hline family split (separation from spouses) & 2.7 & 1.9 \\
\hline death of nearest family member & 3.1 & 1.7 \\
\hline drinking coffee more than three times a day & 1.8 & 1.0 \\
\hline smoking more than one packet of cigarettes a day & 1.9 & 1.1 \\
\hline regular nights out & 4.1 & 1.9 \\
\hline poor physical condition & 4.9 & 1.8 \\
\hline personal hygiene & 2.0 & 1.5 \\
\hline
\end{tabular}

Table 2: Summary of regression for $\mathrm{HI}$

\begin{tabular}{|l|l|l|l|l|}
\hline Model & $R$ & R Square & Adjusted R Square & Std. Error of Estimate \\
\hline 1 & $0,587^{\mathrm{a}}$ & 0,344 & 0,342 & 1,410 \\
\hline 2 & $0,626^{\mathrm{b}}$ & 0,392 & 0,387 & 1,361 \\
\hline 3 & $0,640^{\mathrm{c}}$ & 0,410 & 0,404 & 1,343 \\
\hline 4 & $0,649^{\mathrm{d}}$ & 0,421 & 0,413 & 1,332 \\
\hline 5 & $0,656^{\mathrm{e}}$ & 0,430 & 0,420 & 1,324 \\
\hline
\end{tabular}

a. Independent variables: (Constant), Unsuitable working conditions (part: do not affect the LBP - low back pain)

b. Independent variables: (Constant), Unsuitable working conditions (part: do not affect LBP, Q23a Dissatisfaction with work: does not affect LBP

c. Independent variables: (Constant), Unsuitable working conditions (part: do not affect LBP, Dissatisfaction with work: does not affect LBP, Work Shift: does not affect LBP d. Independent variables: (Constant), Unsuitable working conditions (part: do not affect LBP, Dissatisfaction with work: does not affect LBP, Work Shift: does not affect LBP, a Job loss: does not affect LBP

e. Independent variables: (Constant), Unsuitable working conditions (part: do not affect LBP, Dissatisfaction with work: does not affect LBP, Work Shift: does not affect LBP, a Job loss: does not affect LBP, disrespectful management relationship: does not affect LBP 
Consequently, only the fifth regression model was considered. On the basis of the variables such as inadequate working conditions, dissatisfaction with work, work shift, job loss, and irreverent attitude, 43.0 percent of the total variability in the incidence of low back pain was explained. The correlation coefficient was 0.656 , and standard error of estimate was 1.324 (see Table 2).

The model suggested that 5 variables out of 17 had a statistically significant effect on the incidence of low back pain, so they were included in the model. The incidence of low back pain was affected by inadequate working conditions, dissatisfaction with job, work shift, job loss, and disrespectful attitude of managers (see Table 4).

The model further suggested that 43.0 percent of the variability in incidence of low back pain can be explained by some psychosocial factors. The regression model was statistically significant $(F=40.617, \alpha=0.000)$. Therefore, the hypothesis "Psychosocial factors cause and effect the occurrence of low back pain among professional drivers" was confirmed.

It was apparent that only the following psychosocial factors had statistically significant effect on the dependent variable: inadequate working conditions, dissatisfaction with work, work shift, job loss, and a disrespectful attitude of managers. The values of standardized regression coefficient were as follows: for the inappropriate working conditions was $0.388(\alpha=0.000)$, for dissatisfaction with work was $0,205(\alpha=0.002)$, for working in shifts was $0.188(\alpha$ $=0.002)$, for job loss was $0.165(\alpha=0.005)$, and for standardized regression coefficient for disrespectful attitude of managers was $0.140(\alpha=0.043)$. All variables, except the disrespectful attitude of managers, had positive impact on the dependent variable. Increasing acceptance of influence for these factors on low back pain meant higher incidence of low back pain, while smaller concurrence with disrespectful attitude meant higher incidence of low back pain. Depending on the value of standardized regression coefficients, unsuitable working conditions had the greatest

\section{Table 3: Statistical significance of regression model 5 in H1}

\begin{tabular}{|c|c|c|c|c|c|c|}
\hline \multicolumn{2}{|c|}{ Model } & $\begin{array}{c}\text { Sum of Squ- } \\
\text { ares }\end{array}$ & $d f$ & Mean Square & $F$ & Sig. \\
\hline \multirow{3}{*}{5} & Regression & 356,187 & 5 & 71,237 & 40,617 &, 000 \\
\cline { 2 - 7 } & The residue & 471,799 & 269 & 1,754 & & \\
\cline { 2 - 7 } & Together & 827,985 & 274 & & & \\
\hline
\end{tabular}

Table 4: Regression coefficients for H1 (Model 5)

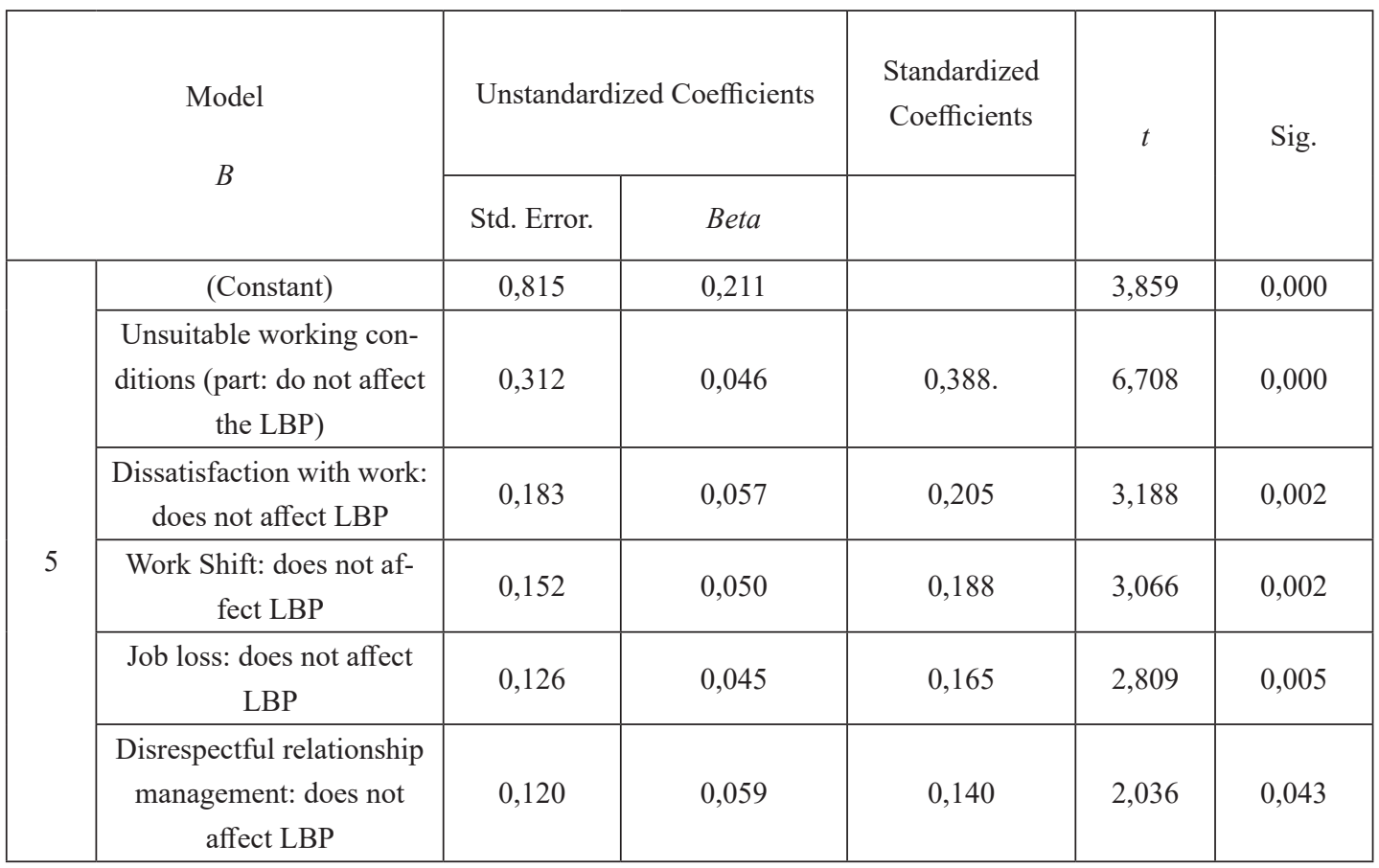


impact on incidence of low back pain, while disrespectful attitude of managers had only minimal influence on incidence of low back pain.

The second hypothesis "The occurrence of low back pain varies according to gender, age and years of work among professional drivers" was verified through a regression model, where independent variables gender, age, and years of working as a professional driver were included. A dependent variable was incidence of low back pain. Hence, the influence of gender, age and years of work as a professional driver on the importance of low back pain was examined.

Model 2: The occurrence of low back pain varies according to gender, age and years of work among professional drivers

Stepwise method was used in order to develop one regression model. This model included the variable age only, which explained 2.5 percent of variability of importance on low back pain. The correlation coefficient was 0.157 , standard error of estimate was 1.946 (see Table 5).

The regression model was statistically significant ( $\alpha$ $<0.05$ ) (see Table 6).

The variable age had statistically significant impact on the incidence of low back pain $(\alpha=0.009)$ (see Table 7).

Age had positive effect on the occurrence of low back pain among professional drivers. The older professional drivers were the stronger their low back pain. Therefore, the hypothesis "The occurrence of low back pain varies according to gender, age and years of work among professional drivers" was confirmed.

The third hypothesis "Occurrence of low back pain varies among different groups of professional drivers" was verified by using analysis of variance (ANOVA). The incidence of low back pain varies among groups of respondents depending on the type of vehicle they drive as professional drivers (bus, lorry internationally, suburban or peripheral, tourist bus, local lorry, tourist bus, car, etc.) was assessed. To verify third hypothesis, the variables incidence of low back pain, and type of vehicle driving by professional drivers were assessed.

Low back pain most frequently occurred among drivers of city buses $(\mathrm{M}=4.0)$, followed by lorry drivers on international routes $(\mathrm{M}=3.8)$, and drivers of suburban or peripheral bus routes $(\mathrm{M}=3.5)$. Fewer problems with low back pain were determined among professional drivers of passenger cars $(\mathrm{M}=3.2)$ (

Analysis of variance suggested that the results were not statistically significant $(\alpha<0.05)$. It showed that among varies groups of professional drivers there were no significant differences in incidence of low back pain (see Table 9).

Therefore, hypothesis "Occurrence of low back pain varies among different groups of professional drivers" was not confirmed.

\section{Discussion and conclusion}

Professional drivers as a group are exposed to high risk of developing low back pain. Namely, while working in often fixed seated position behind the wheel, they are confronted with whole-body vibration, forced position, and heavy handlings of goods. Low back pain among professional drivers is more common than in professions where work is

Table 5: Summary of the regression model for $\mathrm{H} 2$

$a$ - Independent variables: (Constant), Age

\begin{tabular}{|c|c|c|c|c|}
\hline Model & $R$ & R Squar & Adjusted R Square & Std. Error of Estimate \\
\hline 1 & $0,157^{\mathrm{a}}$ & 0,025 & 0,021 & 1,946 \\
\hline
\end{tabular}

Table 6: Statistical significance of the regression model for $\mathrm{H} 2$

\begin{tabular}{|c|c|c|c|c|c|c|}
\hline \multicolumn{2}{|c|}{ Model } & Sum of Squares & Df & Mean Square & $F$ & Sig. \\
\hline \multirow{2}{*}{$\begin{array}{c}\text { The residue } \\
\text { Together }\end{array}$} & Regression & 26,174 & 1 & 26,174 & 6,914 &, $009^{\mathrm{b}}$ \\
\cline { 2 - 8 } & 1033,463 & 273 & 3,786 & & & \\
\cline { 2 - 8 } & 1059,636 & 274 & & & & \\
\cline { 2 - 8 }
\end{tabular}

a. Dependent Variable: LBP is: medium

b. Independent variables: (Constant), Age 
carried out in changing body positions.

Ergonomic factors associated mainly with uncomfortable seats and uncomfortable back supports are commonly stated as causes for low back pain. Our study suggests that psychosocial factors are also important cause for the development of low back pain among professional drivers that can limit the quality of their social and professional lives. Risk factors are various and include prolonged sitting, forced body position, exposure to whole-body vibration, and other parallel factors such as heavy lifting, poor diet and a number of other psychosocial factors. The study assumed that gender, age and years of work as a professional driver can impact the occurrence of low back pain, but we could not confirm that in its entirety. The study shows that professional drivers are frequently confronted with acute low back pain that can last up to 6 months. The older professional drivers (i.e., more years of work as professional drivers) the stronger their low back pain problems. Gender differences exist, although low back pain is more typical for women, and are statistically significant among professional drivers.

Our study further shows that low back pain is more often among bus drivers and lorry drivers on international routes than among professional drivers of vans and passenger cars, but without any statistical significance. Professional drivers, as a profession, are very exposed to diseases of the locomotor system, especially the lower spine, and based on the findings of the study we can conclude that there are differences among various groups due to differ- ent nature of their work. Namely, bus and lorry drivers are during their work behind the wheel practically all the time and do not have so many opportunities for rest and exercise like professional drivers of passenger cars do. The latter, on average, drive shorter distances, and often leave their vehicles. Professional drivers of vans and passenger cars namely have more time to rest and relax (stretch their legs). In order to prevent low back pain they exercise once a week, rest actively or devote their time to rest from one to two hours.

The present study represents a significant contribution to new knowledge in the field of management and governance of organizations. Its key contributions are in directing the awareness of theorists and practitioners about the importance of workplace health and lack of in-depth design, practical programs and holistic treatment. Fast technological development, sharp competition, globalisation and similar trends are forcing companies to have proper developmental goals connected to their employees. It is therefore a priority task of them to secure a high-quality human resource structure, primarily focused on raising the levels of productivity, efficiency, creativeness, innovativeness and safety at work (Sprajc, Sifrer, Novak, 2011). Also, we consider human resource management's way of functioning as a strategic partner in a company with a healthy orientation (Sprajc, Podbregar, 2016). Clarification in the scientific literature differently defined narrow scientific fields. Our aim is to clarify the unexplained holistic psychosocial risk factors and treatment effects on the

Table 7: Regression coefficients for $\mathrm{H} 2$

\begin{tabular}{|c|c|c|c|c|c|c|}
\hline & \multirow{2}{*}{$\begin{array}{c}\text { Model } \\
\qquad B\end{array}$} & \multicolumn{2}{|c|}{$\begin{array}{c}\text { Unstandardized } \\
\text { Coefficients }\end{array}$} & \multirow[t]{2}{*}{$\begin{array}{c}\text { Standardized } \\
\text { Coefficients }\end{array}$} & \multirow[t]{2}{*}{$t$} & \multirow[t]{2}{*}{ Sig. } \\
\hline & & Std. Error. & Beta & & & \\
\hline \multirow{2}{*}{1} & (Constant) & 2,189 & 0,563 & & 3,888 & 0,000 \\
\hline & Age: & 0,035 & 0,013 & 0,157 & 2,629 & 0,009 \\
\hline
\end{tabular}

Table 8: The average incidence of low back pain among professional drivers of various vehicles

\begin{tabular}{|c|c|c|c|}
\hline Professional driver & N & M & s.o. \\
\hline City bus & 70 & 4,0 & 1,8 \\
\hline Lorry (international) & 44 & 3,8 & 1,8 \\
\hline Suburban or peripheral bus & 32 & 3,5 & 1,5 \\
\hline Lorry (local) & 31 & 3,4 & 1,5 \\
\hline Other & 18 & 3,3 & 2,0 \\
\hline Tourist bus & 8 & 3,3 & 1,0 \\
\hline Passenger car & 72 & 3,2 & 1,8 \\
\hline
\end{tabular}


Table 9: Analysis of variance

\begin{tabular}{|l|l|l|l|l|l|}
\hline & Sum of Squares & of & Mean Square & F & Sig. \\
\hline Between groups & 27,765 & 6 & 4,627 & 1,550 & 0,162 \\
\hline Within groups & 800,221 & 268 & 2,986 & & \\
\hline Together & 827,985 & 274 & & & \\
\hline
\end{tabular}

health of the population of the professional drivers. Such factors can lead to absenteeism. The study provides an initial demonstration research in the Slovenian practice. Furthermore, it provides solutions in a holistic approach to solve the problem managing risk factors.

To deepen our knowledge about how low back pain occurs among professional drivers, it would be interesting for future studies to continue longitudinal research in various groups of drivers and to focus on more (or all) psychosocial factors. Development of standardized questionnaire with the help of experts is a recommended approach, and more representative samples may provide a better basis for the generalization of the results.

\section{Literature}

Adams, M.A., Mannion, A.F., \& Dolan, P. (1999). Personal risk factors for first-time low back pain. The Spine Journal, 24(23), 2497-2505, http://dx.doi. org/10.1097/00007632-199912010-00012

Alcouffe, J., Manilier, P., Brehier, M., Fabin, C. \& Faupin, F. (1999). Analysis by sex of low back pain among workers from small companies in the Paris area: severity and occupational consequences. Occupational Environment Medicine 1999, 56(10), 696-701. http:// dx.doi.org/10.1136/oem.56.10.696

Alperovitch Najenson, D., Santo, Y., Masharawi, Y., Katz-Leurer, M., Ushvaev, D. \& Kalichman, L. (2010). Low back pain among professional bus drivers: ergonomic and occupational-psychosocial risk factors. The Israel Medical Association Journal, 12(1), 26-31.

Aronoff, G.M., Feldman, J.B. \& Campion, T.S. (2000). Management of chronic pain and control of long-term disability. Occupational Medicine, 15(4), 755-770.

Askenazy, P., Cartron, D. \& Prunier-Poulmaire, S. (Eds.). (2014). L'absentéisme, un symptôme des liens entre travail et santé (Research report). France: Paris School of Economics.

Bach, M. P. \& Cosic, D. (2008). Data mining usage in health care management: literature survey and decision tree application. Medicinski glasnik, 5(1), 57-64.

Bilban, M. (2014). Professional drivers in road transport. In A. Zupan and M. Bilban (Eds), Evaluation of the Ability to drive a Car. Conference Proceedings (pp.311-320). Ljubljana: University Rehabilitation In- stitute RS - Soča.

Boslaugh, S. \& Watters, P. (2008). Statistics in a Nutshell: A Desktop Quick Reference. O'Reilly Media, Inc., Sebastopol.

Bouffartigue, P., Pendariès, J. R. \& Bouteiller, J. (2010). La perception des liens travail/santé, Le rôle des normes de genre et de profession. Revue Française de Sociologie, 51, 247-280, http://doi.org/10.3917/rfs.512.024

Bovenzi, M. (2010). A longitudinal study of low back pain and daily vibration exposure in professional drivers. Industrial Health, 48(5), 584-595. http://doi. org/10.2486/indhealth.MSWBVI-02

Breuer, R. \& Brettel, M. (2012). Short- and Long-term Effects of Online Advertising: Differences between New and Existing Customers. Journal of Interactive Marketing, 26(3), 155-166. http://doi.org/10.1016/j. intmar.2011.12.001

Campbell, C. \& Guy, A. (2007). Why Can't They Do Anything for a Simple Back Problem? A Qualitative Examination of Expectations for Low Back Pain Treatment and Outcome. Journal of Health Psychology, 12(4), 641-652. https://doi.org/10.1177/1359105307078171

Chen, J.C., Chang, W.R., Chang, W. \& Christiani, D. (2005). Occupational factors associated with low back pain in urban taxi drivers. Occupational Medicine, 55(7), 535-540. https://doi.org/10.1093/occmed/ kqi125

Cox, J.M. (2011). Low Back Pain: Mechanism, Diagnosis and Treatment. $7^{\text {th }}$ Edition. Philadelphia: Wolters Kluwer.

Dedessus-Le-Moustier, N. \& Lerouge, L. (2011). Une réflexion syndicale contrastée sur la prévention des risques psychosociaux. Revue de droit du travail, 11, 627-633.

Devereux, J.J., Buckle, P.W. \& Vlachonikolis, I.G. (1999). Interactions Between Psychosocial Risk Factors at Work Increase the Risk Disorderss: An Epidemiological Approach. Occupational and Environmental Medicine, 56, 343-353.

Funakoshi, M., Tamura, A., Taoda, K., Tsujimura, H. \& Nishiyama, K. (2003). Risk factors for low back pain among drivers in Japan. Sangyo Eiseigaku Zasshi, 45(6), 235-247.

Frymoyer, J. \& Cats-Baril, W. (1991). An overview of the incidences and costs of low back pain. The Orthopedic 
Clinics of North America, 22(2), 263-271.

Gangopadhyay, S. \& Dev, S. (2012). Effect of low back pain on social and professional life of drivers of Kolkata. Work, 41(1), 2426-2433. https://doi.org/10.3233/ WOR-2012-0652-2426

Gimeno, D., Benavides, F.G., Mira, M., Martinez, J.M. \& Benach, J. (2004). External validation of psychological job demands in a bus driver sample. Journal of Occupational Health, 46, 43-48, http://dx.doi.org/10.1539/ joh. 46.4

Gregg, C. D., McIntosh, G., Hall, H., Watson, H., Williams, D. \& Hoffman, C.W. (2015). The relationship between the Tampa Scale of Kinesiophobia and low back pain rehabilitation outcomes. The Spine Journal, 15(12), 2466-2471. https://doi.org/10.1016/j. spinee.2015.08.018

Grossi, G., Soares, J. J., Ängeslevä, J. \& Perski, A. (1999). Psychosocial correlates of long-term sick-leave among patients with musculoskeletal pain. Pain, 80(3), 607-620. https://doi.org/10.1016/S03043959(98)00253-X

Hanscom, D.A., Brox, J.I. \& Bunnage, R. (2015). Defining the Role of Cognitive Behavioral Therapy in Treating Chronic Low Back Pain: An Overview. Global Spine Journal, 5(6), 496-504. https://doi. org/10.1055/s-0035-1567836

Harris, S. A. \& Rampersaud, Y.R. (2015). The importance of identifying and modifying unemployment predictor variables in the evolution of a novel model of care for low back pain in the general population. The Spine Journal, 16(1), 16-22. https://doi.org/10.1016/j. spinee.2015.09.034

Hartvigsen, J., Leboeuf-Yde, C., Lings, S., Elisabeth, H. \& Corder, E.H. (2000). Review Article: Is sitting-whileat-work associated with low back pain? A systematic, critical literature review. Scandinavian Journal of Social Medicine, 28(3), 230-239. https://doi.org/10.1177/ 14034948000280030201

Hasle, P. (2007). Outsourcing and employer responsibility: A case study of occupational health and safety in the Danish public transport sector. Relations Industrielles, 62, 96-117. http://dx.doi.org/10.7202/015799ar

Hopayian, K. \& Notley, C. (2014). A systematic review of low back pain and sciatica patients' expectations and experiences of health care. The Spine Journal, 14(8), 1769-1780. http://dx.doi.org/10.1016/j. spinee.2014.02.029

International Spine Study Group, J.K. Scheer, J.L. Gum, M.P. Kelly, F.J. Schwab, R.A. Hostin Jr., V. Lafage, S. Bess, and others. (2015). Ratio of Disability to Deformity Burden in 264 Adult Spinal Deformity Patients with Two-Year Follow-up: Novel Insight into Drivers of Disability. The Spine Journal, 15(10), S155. http:// dx.doi.org/10.1016/j.spinee.2015.07.173

Linton, S. J. (2001). Occupational psychological factors increase the risk for back pain: a systematic review. Journal of occupational rehabilitation, 11(1), 53-66. https://doi.org/10.1023/A:1016656225318

Janwantanakul, P. \& Akkarakittichoke, N. (2017). Seat Pressure Distribution Characteristics During 1 Hour Sitting in Office Workers With and Without Chronic Low Back Pain. Safety and Health at Work, in press.

Jones, W., Haslam, R. \& Haslam, C. (2013). Bus drivingCan it be a good job? In Anderson M. (Ed.), Contemporary ergonomics and human factors (pp. 69-76). London: Taylor \& Francis.

Kerr, M. S., Frank, J. W., Shannon, H. S., Norman, R. W. K., Wells, R. P., Neumann, P. \& Bombardier, C. (2001). Biomechanical and Psychosocial Risk Factors for Low Back Pain at Work. American Journal of Public Health, 91(7), 1069-1075.

Knauer, S.R., Freburger, J.K. \& Carey, T.S. (2010). Chronic Low Back Pain Among Older Adults: A Population-Based Perspective. Journal of Aging and Health, 22(8), 1213-1234. https://doi. org/10.1177/0898264310374111

Knox, J.B, Orchowski, J.R., Scher, D. L., Owens, B.D., Burks, R. \& Belmont, P.J. (2014). Occupational driving as a risk factor for low back pain in active-duty military service members. The Spine Journal, 14(4), 592-597. http://doi.org/10.1016/j.spinee.2013.06.029

Kresal, F., Roblek, V., Jerman, A. \& Meško, M. (2015). Lower back pain and absenteeism among professional public transport drivers. International Journal of Occupational Safety and Ergonomics, 21(2), 166-172. http://dx.doi.org/10.1080/10803548.2015.1029289

Krčevski Škvarc, N. (2001). Low back pain therapy. Krka in medicine and pharmacy, 22(1), 16-21.

Leclerc, A. (2017). Work-related physical exposure and low back pain. Occupational and Environmental Medicine, 74(3), 161-162. http://dx.doi.org/10.1136/ oemed-2016-103986

Lerouge, L. (2014). Droit de la santé-sécurité et risques psychosociaux au travail: Où situer le système français au regard des systèmes étrangers? In Lerouge L. (Ed.), Risques psychosociaux en droit social: Approche juridique comparée France/Europe/Canada/ Japon (pp. 4-19). Paris, France: Dalloz.

Linton, S. J. (2001). Occupational psychological factors increase the risk for back pain: a systematic review. Journal of occupational rehabilitation, 11(1), 53-66. https://doi.org/10.1023/A:1016656225318

Louit-Martinod, N., Chanut-Guieu, C., Kornig, C. \& Méhaut, P. (2016). “A plus Dans le Bus” Work-Related Stress Among French Bus Drivers. SAGE Open, 6 (1). https://doi.org/10.1177/2158244016629393

MacNeela, P., Gibbons, A., McGuire, B \& Murphy, A. (2010). "We Need to Get You Focused": General Practitioners' Representations of Chronic Low Back Pain Patients. Qualitative Health Research, 20(7), 977-986. 
https://doi.org/10.1177/1049732310364219

Magora, A. (1973). Investigation of the relation between low back pain and occupation. Psychological aspects, Scandinavian Journal of Rehabilitation Medicine, 5, 191.

Margan, A.Č., Turk, Z. \& Palfy, M. (2009). The Impact of Low Back Pain on Temporary Incapacity for Work. Zdravniški vestnik, 78(12), 726-734.

McBeath, A. (1970). The problem of low back pain. Wisconsin Medical Journal, 69, 208.

McGill, S. (2016). Low Back Disorders: Evidence-Based Prevention and Rehabilitation. Backfitpro, Inc.

Meško, M., Jerman, A. \& Kresal, F. (2012a). Pain in lower back and a lifestyle of professional city bus drivers. In: F. Kresal, P. Jankovič (Eds), Best practices in physiotherapy treatments: conference proceedings (pp.161-169). Ljubljana: Slovenian Chamber of Physiotherapists.

Meško, M., Videmšek, M., Štihec, J., Šinigoj, T., Šuc, L., Karpljuk, D. \& Lavrenčič, J. (2012b). Estimated state of health and stress among truck drivers with regard to participating in recreational sport activities. African Journal of Business Management, 6(31), 9085-9091. http://doi.org/10.5897/AJBM11.2750

Miyamoto, M., Konno, S., Gembun, Y., Liu, X., Minami, K., \& Ito, H. (2008). Epidemiological Study of Low Back Pain and Occupational Risk Factors among Taxi Drivers. Industrial Health, 46(2), 112-117. http://doi. org/10.2486/indhealth.46.112

Okunribido, O.O., Shimbles, S.J., Magnusson, M. in Pope, M. (2007). City bus drivers and low back pain: a study of the exposures to posture demands, manual materials handling and whole-body vibration. Applied Ergonomics, 38(1), 29-38. http://doi.org/10.1016/j.apergo.2006.01.006

Papageorgiou, A.C., Macfarlane, G.J., Thomas, E., Croft, P.R., Jayson, M.I. \& Silman, A.J. (1997). Psychosocial factors in the workplace - do they predict new episodes of low back pain? Spine, 22(10), 1137-1142, http://dx. doi.org/10.1097/00007632-199705150-00014

Proctor, T., Gatchel, R.J. \& Robinson, R.C. (1999). Psychosocial factors and risk of pain and disability. Occupational Medicine (Philadelphia, Pa.), 15(4), 803-812.

Rabenu, E \& A. Tziner (2016). Selection of Employees with Disabilities - Has the Burden on the Employer Become Too Heavy? Amfiteatru Economic, 18(42), 423 - 431.

Rehn, B., Lundström, R., Nilsson, T., Bergdahl, I.A., Ahlgren, C., From, C., Sundelin, G. \& Järvholm, B. (2005). Symptoms of Musculoskeletal Disorders among Drivers of All-Terrain Vehicles in Northern Sweden. Noise \& Vibration Worldwide, 36(1), 13-18. http.//dx.doi.org/10.1260/0957456053499158

Roblek, V. \& Bertoncelj, A. (2014). Impact of corporate social responsibility on the OTC drugs consumers.
Amfiteatru Economic, 16(35), 12-25.

Shojaei, I., Salt, E.G., Hooker, Q., Van Dillen, L.R. \& Bazrgari, B. (2017). Comparison of lumbo-pelvic kinematics during trunk forward bending and backward return between patients with acute low back pain and asymptomatic controls. Clinical Biomechanics, 41(1), 66-71, http://dx.doi.org/10.1016/j.clinbiomech.2016.12.005

Sprajc, P., Sifrer, J. \& Novak, V. (2011). Economic growth effects on education with the emphasis on the career center. E+M Ekonomie a Management, 14(2), 51-64.

Sprajc, P. \& Podbregar, I. (2016). Internal marketing as a strategic tool of human resource management. In $\mathrm{O}$. Arsenijevic, (ed.), Enterpreneurship for a suistanable economy (pp.189-204). Belgrade: Faculty of Business Studies and Law.

Szeto, Y.P.G. \& Lam, P. (2007). Work-related Musculoskeletal Disorders in Urban Bus Drivers of Hong Kong. Journal of Occupational Rehabilitation, 17(2), 191198. . http://dx.doi.org/10.1007/s10926-007-9070-7

Šinigoj, T., Karpljuk, D., Videmšek, M., Štihec, J. \& Meško, M. (2011). Športne aktivnosti in življenjski slog voznikov tovrnjakov. [Sports activity and lifestyle of truck drivers.] Šport, 59(3/4), 93-97.

Tamrin, S.B., Yokoyama, K., Jalaludin, J., Aziz, N.A., Jemoin, N., Nordin, R., Li Naing, A., Abdullah, Y. \& Abdullah, M. (2007). The association between risk factors and low back pain among commercial vehicle drivers in peninsular Malaysia: a preliminary result. Industrial Health, 45(2), 268-278, http://doi. org/10.2486/indhealth.45.268

Thorbjörnsson, C.B., Alfredsson, L., Fredriksson, K., et al. (2000). Physical and Psychosocial Factors Related to Low Back Pain During a 24-Year period. A nested case-control analysis. Spine, 25(3), 369-375.

Tse, J.L.M., Flin, R. \& Mearns, K. (2006). Bus driver well-being review: 50 years of research. Transportation Research, Part F 9, 89 -114. http://dx.doi. org/10.1016/j.trf.2005.10.002

Tziner, A. \& A. Birati (2015). Assessing the Financial Value of Human Resource Management Programs and Employee Behaviors: A Critical Tool Still Coming of Age. Amfiteatru Economic, 17(9), 1259 - 1272.

Van der Beek, A.J. (2012). World at work: truck drivers. Occupational and Environmental Medicine, 69(4) 29129. http://dx.doi.org/10.1136/oemed-2011-100342

Videman, T., Simonen, R., Usenius, J.-P., Österman, K. \& Battié, MC. (2000). The long-term effects of rally driving on spinal pathology. Clinical Biomechanics, 15(2), 83-86. http://dx.doi.org/10.1016/S02680033(99)00047-9

Waddell, G. (1998). The Back Pain Revolution. Edinburgh, Churchill Livingstone, 24-375.

Walsch, K., Crudas, M. \& Coggon, D. (1992). Low back pain in eight areas of Britain. Journal of Epidemiology and Community Health, 46(3), 227-230. http://dx.doi. 
org/10.1136/jech.46.3.227

Xu, Y., Bach, E. \& Ørhede, E. (1997). Work Environment and Low Back Pain: The Influence of Occupational Activites. Occupational and Environmental Medicine, 54(10), 741-745. http://dx.doi.org/10.1136/ oem.54.10.741

Yoo, W-G. (2016). Effect of unilateral exercises on low back pain in an urban driver. Journal of Physical Therapy Science, 28(11), 3257-3258. http://doi.org/10.1589/ jpts.28.3257

Friderika Kresal, Ph.D., Assistant Professor, is the dean of private independent Higher educational institution Fizioterapevtika. Her scientific and research work is focused on lower back pain and causes for it. She is the author or co-author of many scientific articles on the subject. As the head of Slovenian Physiotherapist Chamber, she is personally responsible for improvements and raise of recognisability of Slovenian physiotherapy. She achieved this through her 20 years of work in the organization as president. In her career, she has participated in many domestic and international conferences both as a author or co-author with her papers.

Tine Bertoncel holds a B.S. in Psychology from the State University of New York and is currently working on his M.Sc. in Neuroscience at Medical Center at the Erasmus University Rotterdam. He co-authored several journal and conference papers.

Maja Meško, PhD, has held a position as associate professor of management at the Faculty of management, Department of management, University of Primorska. She also has a certificate for associate professor of kinesiology (science in sport) at the Faculty of sport, University of Ljubljana. Her main teaching and research areas include management, psychology in management, organizational culture, health and sport psychology where she authored or co-authored various scientific papers. 